\title{
Industrial Clusters as Drivers of Sustainable Regional Economic Development? An Analysis of an Automotive Cluster from the Perspective of Firms' Role
}

\author{
Xiaofei Chen ${ }^{1}$, Enru Wang ${ }^{1,2, *}$, Changhong Miao ${ }^{1,3}$, Lili Ji ${ }^{4}$ and Shaoqi Pan ${ }^{3}$ \\ 1 Key Research Institute of Yellow River Civilization and Sustainable Development \& Collaborative \\ Innovation Center on Yellow River Civilization of Henan Province, Henan University, \\ Kaifeng 475001, China; chenfei_niglas@163.com (X.C.); chhmiao@henu.edu.cn (C.M.) \\ 2 Department of Geography and Geographic Information Science, University of North Dakota, \\ Grand Forks, ND 58202, USA \\ 3 The College of Environment and Planning, Henan University, Kaifeng 475001, China; psq@henu.edu.cn \\ 4 School of Education, Henan University, Kaifeng 475001, China; zkmjili@163.com \\ * Correspondence: enru.wang@und.edu
}

Received: 21 February 2020; Accepted: 30 March 2020; Published: 3 April 2020

\begin{abstract}
This paper examined the relationships among firms in a rapidly growing specialized industrial cluster-the Chery automotive cluster located in the Wuhu Economic and Technology Development in eastern China. After demonstrating how the Chery automotive cluster contributed to sustainable regional economic development, it focused on defining the roles that major firms play in the localized production network. Based on three attributes of the firm (network linkages, network position, and network power), the study identified a typology of firms' role, including the dominant core, lead firms, gatekeepers, intermediaries, club of foreigners, peripherals, and loners. By revealing the heterogeneity of the firms and discussing the differing roles they play in the network, the paper made some policy recommendations to promote the sustainable development of the cluster, including providing policy supports to core firms, encouraging inter-firm networking and interaction, and diversifying the cohort of gatekeepers.
\end{abstract}

Keywords: industrial cluster; production network; sustainable regional development; firm's role; automotive cluster; Chery; China

\section{Introduction}

One of main challenges that regions face in sustainable development is achieving sustainable economic growth while minimizing environmental impacts. In a globalized world, an important development strategy of regions lies in embedding themselves in the global production network through developing or attracting industries, especially higher-value added and less-polluting industries. Fostering industrial clusters is considered one important approach to improving regional competitiveness.

Industrial clusters are geographical concentrations of firms from the same economic sector, along with specialized suppliers, service providers, firms in related industries and local institutions [1]. The benefits of clustering arise from localized agglomeration economies, including local information and knowledge spillovers, local supply of non-traded inputs, and a skilled local labor pool [2]. In addition to the intra-industry spillovers through the co-location of specialized activities pertaining to the same industry, inter-industry spillovers occur when firms forge backward and forward linkages with local 
suppliers and customers, and favor cooperation and creation of new ideas across sectors [3,4]. Together, industrial clustering may result in greater regional exports and employment growth, and thus promote sustainable economic growth [5].

It is essential to understand the roles that firms play or the positions they occupy within the local agglomeration. On one hand, it helps researchers, planners, and policy makers understand how the industrial cluster is organized and functions so that they can monitor the health of the industrial cluster. As has happened repeatedly, the poor performance of a lead firm or industry may generate the multiplier effect that ripples through the regional economy and beyond. It is usually the linked firms within the local agglomeration that are affected most. From a regional planning perspective, a study of how industries and firms relate to one another in the cluster (e.g., the roles that firms play or the positions they occupy within the local agglomeration) will help planners and policy makers understand how the industrial cluster is organized and functions so that they can monitor the health of the industrial cluster and help the region achieve sustainable economic development. By knowing the roles of firms, businesses and local leaders will be able to assess the players with growth potential or hidden risk and take measures to promote growth or minimize loss. On the other hand, recognizing the roles that firms play will help local officials take advantage of the "locational opportunities" that economic globalization and industrial transfer bring to the newly industrializing economies (NIEs) [6], and formulate industrial policies to attract needed businesses, which is important for upgrading regional production capacity and leapfrogging regional economic growth.

However, even a local industrial cluster presents a complex network of interaction. The role that firms play within the network is not always obvious. The purpose of this paper is to identify and define the role that major firms play in an industrial cluster and to sort out the relationships among them. Using the Chery automotive cluster in Wuhu, China as the case study, the research aims to reveal the heterogeneity of the firms in a rapidly growing specialized cluster and to demonstrate how to identify the role that the firms play. By doing so, the paper makes some policy recommendations for the local government on the sustainable development of the industrial cluster.

In what follows, we first provide a brief review of economic geography literature on industrial clusters. Then, we move to introduce research background, data source, and research methods that we use in the study. Major results are presented in Section 4, followed by a discussion of some influencing factors. The paper concludes with a summary of major findings and a discussion of policy implications.

\section{Literature Review and Analytical Framework}

Economic geographers and researchers in other disciplines have made deliberate efforts to understand firms' role in an industrial cluster in relation to the cluster's contribution to sustainable regional development. Studies in this area can be divided into several interrelated streams based on the major approach or perspective taken.

The first stream of research is based on the global value chain (GVC) or global production network (GPN) framework. GVCs are usually coordinated by large transnational corporations (TNCs). With the capability of coordinating different and dispersed activities in a chain, these TNCs become "governor firms" or "chain governors" [7-11]. Governor firms set production parameters and exert strong influence over other firms by setting conditions under which firms participate and by determining the division of labor in the chain.

The GVC approach provides a valuable tool for us to understand the prospects and processes of industrial upgrading. By emphasizing the dominant role of lead firms, or governors, the GVC literature suggests that the upgrading prospects of local firms are determined from outside the locality. Overall, the GVC approach focuses on the vertical distribution of power in a chain but tends to overlook the relationships within the locality, such as horizontal co-operation between local producers and peer-to-peer diffusion of knowledge that are common in competitive industrial clusters [12]. The GPN approach has partially addressed this shortcoming by emphasizing the "strategic coupling" of lead firms and local institutions in the locality's effort to be positioned in and integrated with the global 
production network [13]. The approach has been used to study how industrial clusters emerge in the context of changing the organization of global production networks in certain industrial sectors [14-16]. Nevertheless, overall, the GPN literature has not given as much attention to how actors interact with each other inside a localized production network as to how they interact with outside players on a larger scale (e.g., global scale).

The second stream of research, which relates to both GPN and GVC approaches, has an explicit focus on power relations within a cluster or local production network. Firms with a power advantage take central positions in the network. Structural factors, such as size, scale, technology, and favorable state policies, tend to give these powerful network members, particularly TNCs, even more power over other suppliers and especially over regionally-based small and medium-sized enterprises within the localized firm networks or industrial clusters [17,18].

The third stream of research that considers the roles of firms takes on an embeddedness perspective. According to this approach, firms are not atomistic entities. Rather, they are embedded in a network of relationships with other firms, which influence the flow of information and resource among them $[19,20]$. Being embedded within a cluster allows firms to gain access to the regional knowledge stock and enables firms to seize opportunities, build social capital, and cultivate cluster advantage, which eventually helps improve firm performance and facilitates sustainable regional growth [21-23]. When embedded in knowledge networks, firms can enhance their innovation performance, especially when they link themselves with technologically related or similar firms [24,25]. Despite its benefits, however, one should not assume that every firm seeks or is able to seek active embeddedness. Depending upon the availability of key local assets or the existence of other influential players, embeddedness may take a different form. For instance, when the localized assets are less ubiquitous but critically important or where access to the assets is controlled by the state, embeddedness is likely to take an obligated form [26]. To overcome local institutional constraints or avoid the limitations that obligated embeddedness causes, some incoming firms may choose suppliers and other associated firms as partners from outside the host region. These firms form a sub-cluster in the host region and are not actively involved in the interaction with local businesses. Most of the economic, technological, and social interactions among the firms take place within the sub-cluster [26,27]. To some extent, these firms form an "enclave [28] or a "club of foreigners" [29-31].

The fourth body of research examines the role and performance of firms from a social network perspective [32]. According to this perspective, an industrial district or cluster is a network of producers, supporting organizations, and a local labor market. Two of the most important properties of the network include network structure and network position [33]. Network structure can be described by several network-analytical measures such as the size of the network, density, connectivity, or the symmetry. The most important measure of an actor's position in the network is centrality, which includes degree centrality, closeness centrality, and betweenness centrality [32,34-36].

The social network literature has paid considerable attention to network position. Network position and characteristics impact firm performance directly [37]. A firm's network position partly determines the constraints and opportunities that the firm will encounter, which affect corporate behaviors such as information gathering, strategic choices, corporate risk-taking, and utilization of corporate resources [38]. A favorable or central position in a network can allow a firm to gather information easily and use the information to negotiate with other firms. It also enables the firm to establish the rules that other firms willingly or unintentionally adopt. Thus, for firms, positioning themselves in a network of relevant firms is increasingly seen as an important strategic option.

Recent studies have examined the role of leading firms as gatekeepers of knowledge, which act as "bridging enterprises", or "brokers", linking the cluster to the outside world and funneling knowledge into organizations through the process of knowledge translation [34]. With a high degree centrality in the localized network, gatekeepers are important players for mobilizing the network and bringing other stakeholders together [35]. 
The above approaches have been used to study the automobile industry or automotive clusters. Drawing on the GVC and GPN perspectives, Pavlínek and Ženka (2010) evaluated industrial upgrading of 490 Czech-based automotive firms during the period of significant inflows of foreign direct investment into the Czech automotive industry between 1998 and 2006 and reported the selective nature of industrial upgrading at the firm level [39]. The study by Li et al. (2016) suggested that integration in GPN and host-country institutional support drove technological upgrading in the automotive industry in China [40].

The automotive industry represents a typical example of captive value chains [10,41]. A small number of lead firms (large assemblers) organize and regulate vertical production networks of component suppliers. They set the basic parameters of automotive GPNs with their corporate and market power [42]. Nevertheless, by working with automotive TNCs or their subsidiaries, domestic suppliers, especially those in semi-peripheral countries (e.g., Czechia, Slovakia, Mexico), could receive technology and knowledge transfer, even though the spillover effects vary depending upon the quantity and quality of supplier linkages between foreign subsidiaries and domestic firms $[41,43,44]$.

Studies have also shown that similar to TNCs in other industries, being effectively embedded in the local network through establishing close business and social relationships with suppliers has been found to be crucial to the successes of TNC subsidiaries in the automotive industry [45,46]. In their study of how automotive component suppliers in Hungary reacted to the 2008-2009 economic crisis, Rugraff and Sass (2018) showed that the embeddedness in dense interactions with other economic agents provided firms with "relational rent", which allowed them to react offensively to economic turmoil [47].

Scholars have also drawn on social network analysis to study automotive clusters. Eisingerich et al. (2010) found that network strength and network openness underpinned high performing regional clusters, including automotive clusters in the Greater Toronto Area and in upper Austria and some other clusters, though the effects of these network characteristics were moderated by environmental uncertainty [48]. By analyzing the knowledge networks of the automotive cluster in southwest Saxony in eastern Germany, Plum and Hassink (2013) showed that firms in this cluster relied heavily on the synthetic knowledge base, whereas the analytical knowledge base (i.e., R\&D activities) was rather weak [49].

The above approaches have contributed to the understanding of the role of particular firms in a network or cluster. However, each of them has some limitations in explaining the heterogeneous role of all firms in the cluster. Taking Foxconn-the world's largest contract electronics manufacturer and a leading original equipment manufacturer-as an example, with tremendous power in the GPN, the company has the capacity to build linkages with various firms to serve its global growth strategy. Following the power relations perspective, one would assume that Foxconn undoubtedly serves as the core firm in an industrial cluster. However, field surveys show that Foxconn rarely seeks to create industrial and technological linkages with local firms. Instead, in a regional production network, Foxconn mostly works with the suppliers and other associated firms that it brings in [50], forming a "club of outsiders". This phenomenon cannot be adequately explained by the embeddedness theory either.

Except for the studies on firms' centrality in the network, most studies on firms' roles or positions have been descriptive. This is presumably due to the difficulty in obtaining data on the formal linkages between firms in the cluster [51].

\section{Methodology}

This study examines an industrial cluster anchored by Chery Automobile ("Chery auto cluster" hereafter) in the Wuhu Economic and Technological Development Zone (Wuhu ETDZ). With a population of 3.7 million in 2017, Wuhu is a prefectural-level city of Anhui Province in eastern China [52]. Located in the Jinghu District to the north of the city (see Figure 1), Wuhu ETDZ, the first national ETDZ in Anhui Province designated in 1993, is home to over 2600 companies, including 
26 foreign Fortune Global 500 companies, 48 domestic listed companies, 93 high-tech enterprises, over 90 research institutes. Automobile and auto parts, domestic electric appliances, and new materials are the three pillar industries [53]. Whereas Wuhu ETDZ is an industrial cluster designated and promoted by the government at different levels (national, provincial, and municipal), the Chery auto cluster is a smaller, specialized (automobile) cluster within the larger Wuhu ETDZ cluster.

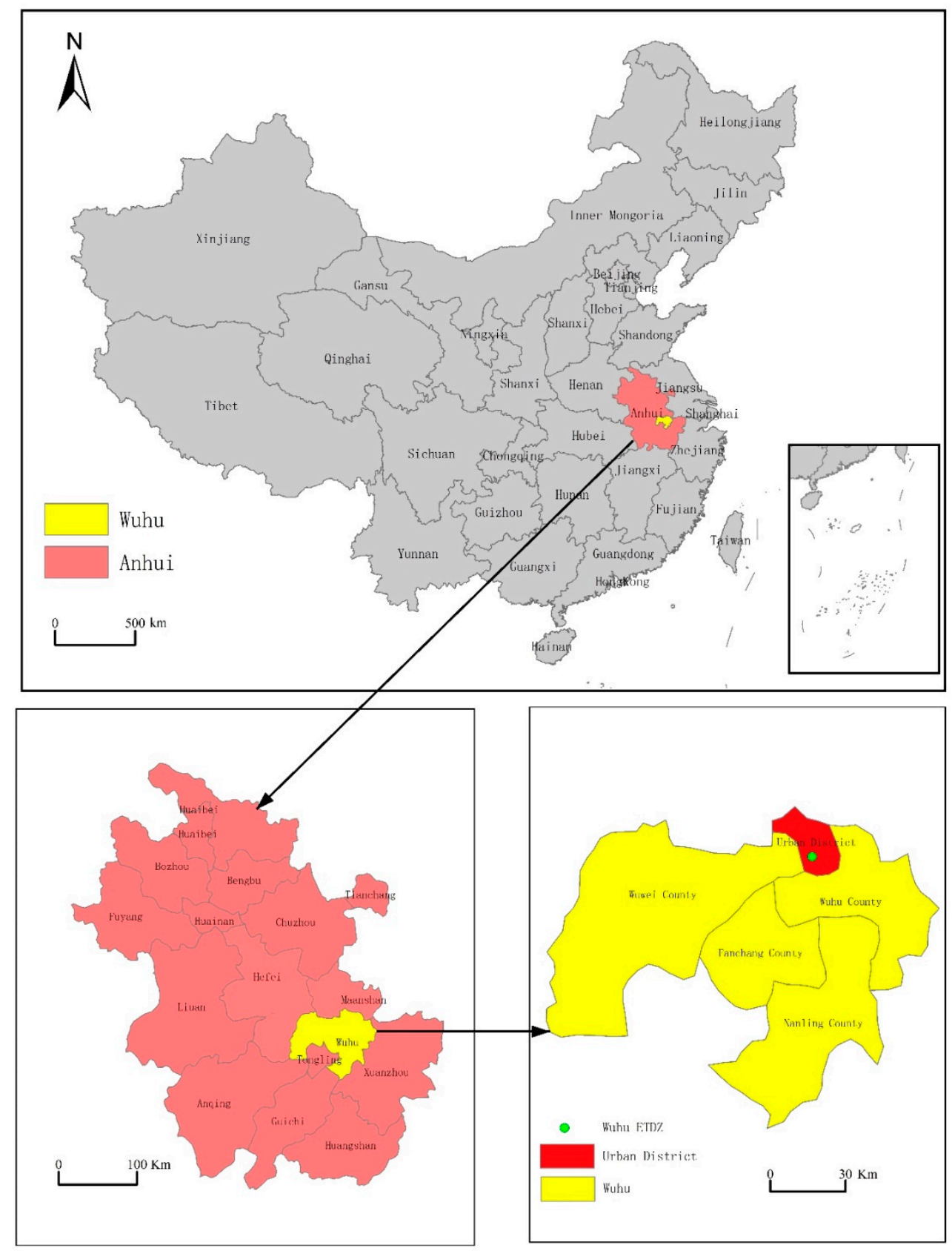

Figure 1. Location of the study area.

This study selected the Chery auto cluster as the case study for two major reasons. First, there have been studies on some larger automotive clusters in China, such as Shanghai, Guangzhou, and Changchun [54-56], though none of these studies focused on the firm's roles within the cluster. Secondly, a rising star in China' automobile industry, Chery has arguably become the most successful example of China's self-branded automobile makers. The company is the largest exporter of passenger vehicles in China. Indeed, Chery's success has made the central government reexamine its decades-long 
joint venture policy for the automobile industry and adopt a new policy favoring indigenous development [57].

Over time, the headquarter base of Chery has attracted dozens of domestic and foreign auto parts manufacturers to the Wuhu ETDZ, providing parts or components for literally all major systems such as powertrain system, body system, chassis system, and electronics system.

In the analysis that follows, we first demonstrate how the two clusters-Wuhu ETDZ and the Chery auto cluster-have contributed to regional economic development. We then focus on analyzing the internal configurations of the cluster by defining the roles that firms play in the localized production network.

\subsection{Data Sources}

In this research, we collected government statistics (at different levels) and company reports to assess the contributions of the Chery auto cluster to the regional economy. To analyze firms' role in the cluster, we took advantage of a unique hand-collected dataset on firm linkages within the Chery auto cluster. The data were collected during September 2015 and January 2016 through interviews and questionnaires. We first sent questionnaires to companies, but the response rate was low, and some returned questionnaires were incomplete. We only received seven complete questionnaires. Therefore, we decided to conduct interviews with other key companies on the list through personal contacts and networking. The interviews were semi-structured following an interview protocol comprised of the key questions from the questionnaire. We were able to successfully interview 36 companies. In total, we received 43 valid questionnaires. Answered by top company officials (e.g., general managers, vice general managers, chief financial officers, etc., who can speak on behalf of the company), the interview and questionnaire questions aimed to understand a firm's relationships with other firms within the Wuhu ETDZ. They covered several areas, including, (1) firm profiles and characteristics (company history, major products, number of employees, R\&D, the reason for investing in Wuhu, etc.); (2) economic linkages (upstream suppliers and downstream customers, production and investment connections with other firms in the Wuhu ETDZ, production outsourcing, etc.); (3) technological connections (joint R\&D among firms, technical supports received from and provided to other firms, collaboration between the firm and research intuitions, etc.); (4) social exchanges (inter-firm social and cultural activities, inter-firm visits, participation in associations and organizations, interactions with government agencies, etc.); and (5) embeddedness (firm's opinions about the services and supports provided by Wuhu ETDZ and local governments, challenges that firms faced, etc.).

In addition, we also interviewed, in a less formal way, people who were familiar with the development of the Chery auto cluster, including factory workers, officials from the Wuhu ETDZ Management Committee and other local government agencies, and local researchers.

Based on the main products and services they provide, we classified the firms into four groups: powertrain system, body system, chassis system, and electronics system. The firms, their origins, and their product categories are listed in Appendix A.

\subsection{Research Design}

In this study, we propose a framework to analyze the role that firms play in the cluster. We argue that a firm's role can be estimated (quantitatively or qualitatively) from three interrelated aspects: inter-firm linkages, network position, and power relations (with other firms). After identifying the firm's role, we investigate the factors that influence the way that a firm plays a particular role in a network and interacts with other firms and institutions (Figure 2). We focus on three major factors, including the firm's internal assets such as firm attributes (origin, size, etc.), the firm's corporate strategies (technological orientation, market orientation, etc.), and the firm's embeddedness (e.g., active embeddedness or obligated embeddedness). 


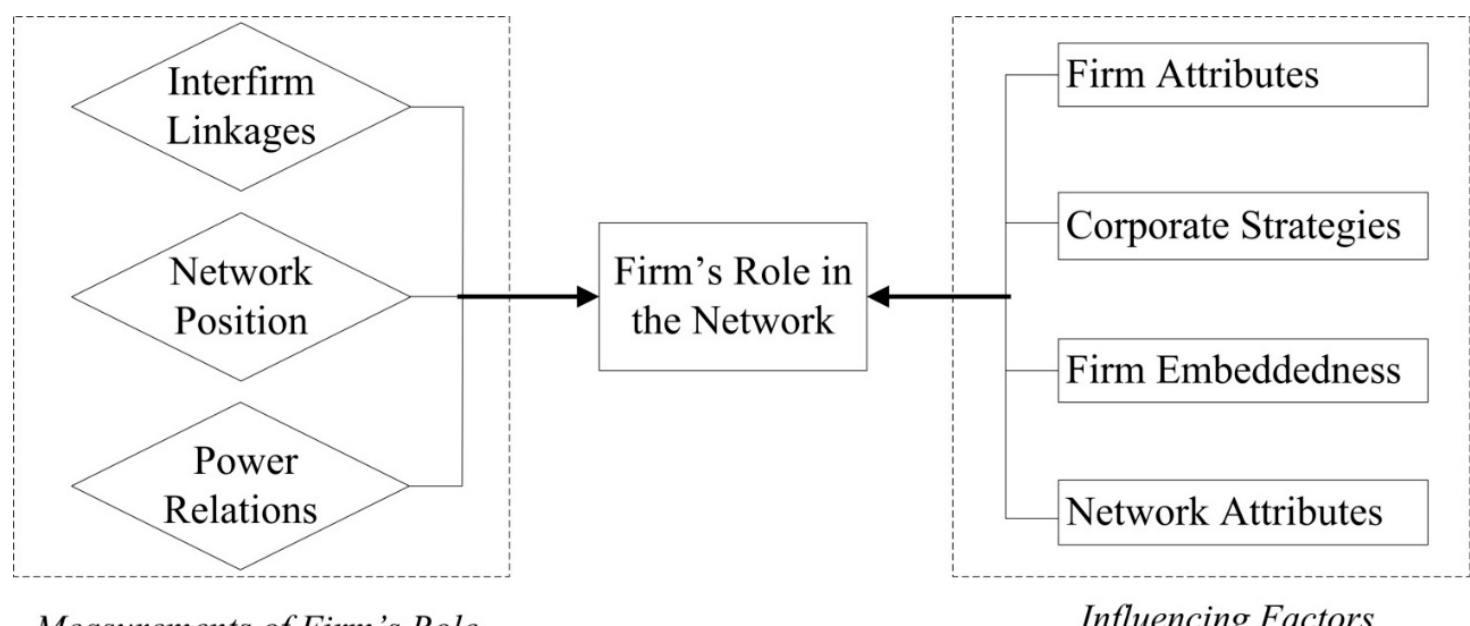

Measurements of Firm's Role

Influencing Factors

Figure 2. Firm's role in the localized production network: an analytical framework.

To define the firm's role, we used both quantitative and qualitative methods to measure the three interrelated aspects: the firm's linkages to other firms, the firm's network position, and the firm's power in relation to other actors in the network.

A firm's linkages to other firms were estimated using a network centrality measurement, degree centrality (or DC hereafter), which determines how many direct connections a firm has to other firms $[32,36]$. It measures the overall centrality and reflects the overall position of a firm in the network. Generally speaking, a firm with a high degree of centrality often occupies an important position in the network and has more network power. The DC of the firm $i$ is calculated as:

$$
C_{D}(\mathrm{i})=\sum_{j \neq i} x_{i j}
$$

Denoting the presence of tie or connection between firms $i$ and $j, x_{i j}$ is 1 if there is tie between $i$ and $j$ and 0 otherwise.

A firm's network position was defined using a combination of multiple methods, including (1) calculating another network centrality measurement, betweenness centrality; (2) decomposing of DC respectively into connections with domestic firms and with foreign firms; and (3) calculating distance matrices in a core-periphery structure created using the social network analysis software UCINET.

The betweenness centrality (or BC hereafter) measures the extent to which a firm acts as an intermediary. The measure is defined under the assumption that communication between two nodes travels along the shortest path, which is called the geodesic path. The BC of firm $i$ takes the form:

$$
C_{B}(\mathrm{i})=\sum_{i \neq j \neq k} \frac{g_{k i j}}{g_{k j}}
$$

where $g_{k i j}$ is the number of geodesic paths linking firms $k$ and $j$ that contain firm $i$, while $g_{k j}$ is the total number of geodesic paths between firm $k$ and firm $j$ with or without involving firm.

Whereas a higher BC suggests a higher likelihood that the firm serves as an intermediary, decomposing the DC would help define other roles that the firm may play. For example, a foreign firm with strong connections with other foreign firms but little interaction with domestic firms in the network could be considered as a member of "club of foreigners". A third measure taken to decide a firm's network position was to calculate distance/adjacency matrices in a core-periphery structure created using the social network analysis software UCINET following Borgatti and Everett (1999) [58]. Originally developed by Linton Freeman in the early 1980s, UCINET is a social network analysis program. Over time, it has evolved into a comprehensive network analysis software package used by 
social scientists to analyze sociometric survey data and network matrix data. Redesigned by Steve Borgatti, Martin Everett, and Linton Freeman, Version 6.6 (the current version as of 2018) provides various network measures of centrality, cliques, density, shortest distance, and many other measures. It also includes a number of tools that enable statistical analyses, such as T-tests and core-periphery tests, multidimensional scaling, factor analysis, cluster analysis, and more. In addition, UCINET and its affiliated mapping program, NetDraw, allow users to generate network maps and diagram. In a distance matrix, firms closest to each other were put in one group. Based on adjacency, UCINET automatically divided firms (as network nodes) into core-core, core-periphery, and periphery-periphery blocks.

A firm's power relations with other firms were estimated based on the qualitative information derived from interviews and questionnaires, in reference to the firm's DC value. We argue that the interaction among the firms in the cluster takes place mainly in three domains: production (or industrial) domain, technological domain, and social domain. Correspondingly, a firm's influence or power within the network may be estimated from three aspects: industrial or productive power, technological power, and social power. A firm that controls crucial production process is considered to have stronger industrial or productive power. For example, an engine-assembly firm, generally speaking, has more power than firms supplying various engine parts or components in the production process. A firm that owns key technologies or provides essential technical supports to other firms in the network, is more technologically powerful. In a similar vein, a firm that plays an active or even leadership role in associations or local community organizations tends to have more social power.

Inspired by Coe and Yeung (2015) [13] and Yeung (2016) [59], we propose a typology of firms' role in the network using a holistic approach (Table 1). Based on measurements of the firm's linkages to other firms, network position, and power relations, firms could be classified into several categories, including "dominant core", "lead firms", "gatekeepers", "intermediaries", "club of foreigners", "peripherals", and "loners". Without doubt, the only dominant core firm is Chery. It is the hub around which the Wuhu automotive cluster revolves. Lead firms have extensive linkages to other firms in the network. They have strong technological capabilities and social impacts. Together with the dominant core, these lead firms are actively involved in network development and governance. Gatekeepers act as bridging firms that link the cluster to the outside world and transmit non-local knowledge into the region. They may occupy less central but still important positions within the network such as structural holes-gaps in the flow of information between subgroups in the network-which gives them an advantage over some other firms because they have an easier access to information and a greater control over the flow of information between disconnected actors. Intermediaries act as connectors that connect two actors or two subgroups of actors that otherwise would not interact. A "club of foreigners" consists of foreign firms that have no or little interaction with domestic or local firms (except for Chery). The linkages they have mostly exist among themselves within the club.

Table 1. A typology of firms' role in the Chery auto cluster.

\begin{tabular}{|c|c|c|c|c|c|c|}
\hline \multirow{2}{*}{ Role Type } & \multicolumn{2}{|c|}{ Linkages with Other Firms } & \multirow{2}{*}{$\begin{array}{l}\text { Network } \\
\text { Position }\end{array}$} & \multicolumn{3}{|c|}{ Power Relations } \\
\hline & Domestic & Foreign & & Industrial & Technological & Social \\
\hline Dominant Core & Strongest & Strongest & Core & Strongest & Strongest & Strongest \\
\hline Lead Firms & Stronger & Stronger & Central & Stronger & Stronger & Stronger \\
\hline Gatekeepers & Strong & Strong & Critical & Strong & Strong & Strong \\
\hline Intermediaries & Uncertain & Uncertain & Intermediate & Weak & Weak & Weak \\
\hline Club of Foreigners & Weak & Strong & Peripheral & Strong & Strong & Weak \\
\hline Peripherals & Weak & Weak & Peripheral & Weaker & Weaker & Weaker \\
\hline Loners & Weak & Weak & Isolated & Weakest & Weakest & Weakest \\
\hline
\end{tabular}

In the network, some firms have very little direct interactions with other firms except for Chery. They generally do not occupy very important positions in the network, so we call them "peripherals". In some extreme cases, some peripherals are very isolated or even standalone. As they do not have connections with other firms, we call these peripherals "loners" (Table 1). It is worth noting that 
some firms may play multiple roles. For example, strictly speaking, lead firms and gatekeepers are also intermediaries.

\section{Findings and Discussions}

In this section, we first briefly demonstrate how the Chery auto cluster contributes to local economic development. Then, we present our findings on the roles and network positions of firms in three separate domains: industrial, technological, and social. Then, we summarize the overall role that each firm played within the industrial cluster through a comprehensive identification, followed by a discussion of the factors that influence the role that a firm plays in the industrial cluster.

\subsection{Industrial Clusters as Drivers of Sustainable Regional Economic Growth}

Wuhu's economy took off after Wuhu ETDZ was created in 1993 and especially after Chery Automobile Co., Ltd. was established in January 1997 headquartered in Wuhu ETDZ. In 1995, GDP per capita in Wuhu City was 4775 yuan, higher than provincial average (3057 yuan) but lower than the national average of 5064 yuan. By the end of 1997, Wuhu's GDP per capita (7650 yuan) exceeded the national average by over 1000 yuan. Since then, the city enjoyed an annual growth rate higher than the provincial and the national averages. While Wuhu ETDZ occupies only $2 \%$ of land of Wuhu with $2.3 \%$ of its population (in 2017), it contributed $17 \%$ of the city's total GDP and $27 \%$ of the industrial value-added.

Within Wuhu ETDZ, the Chery auto cluster contributed nearly $40 \%$ of the Wuhu ETDZ's GDP every year during 2008-2014, over 40\% of foreign direct investment (FDI) attracted, and over 35\% of total export. Indeed, Wuhu ETDZ and the Chery auto cluster have become very important drivers of sustainable economic growth for the city of Wuhu.

\subsection{Firms' Role within the Chery Auto Cluster}

\subsubsection{Firms' Role by Domain}

Using UCINET, we mapped the industrial, technological, and social linkages of firms respectively. Figure 3 provides visualizations of the configurations of the three networks.

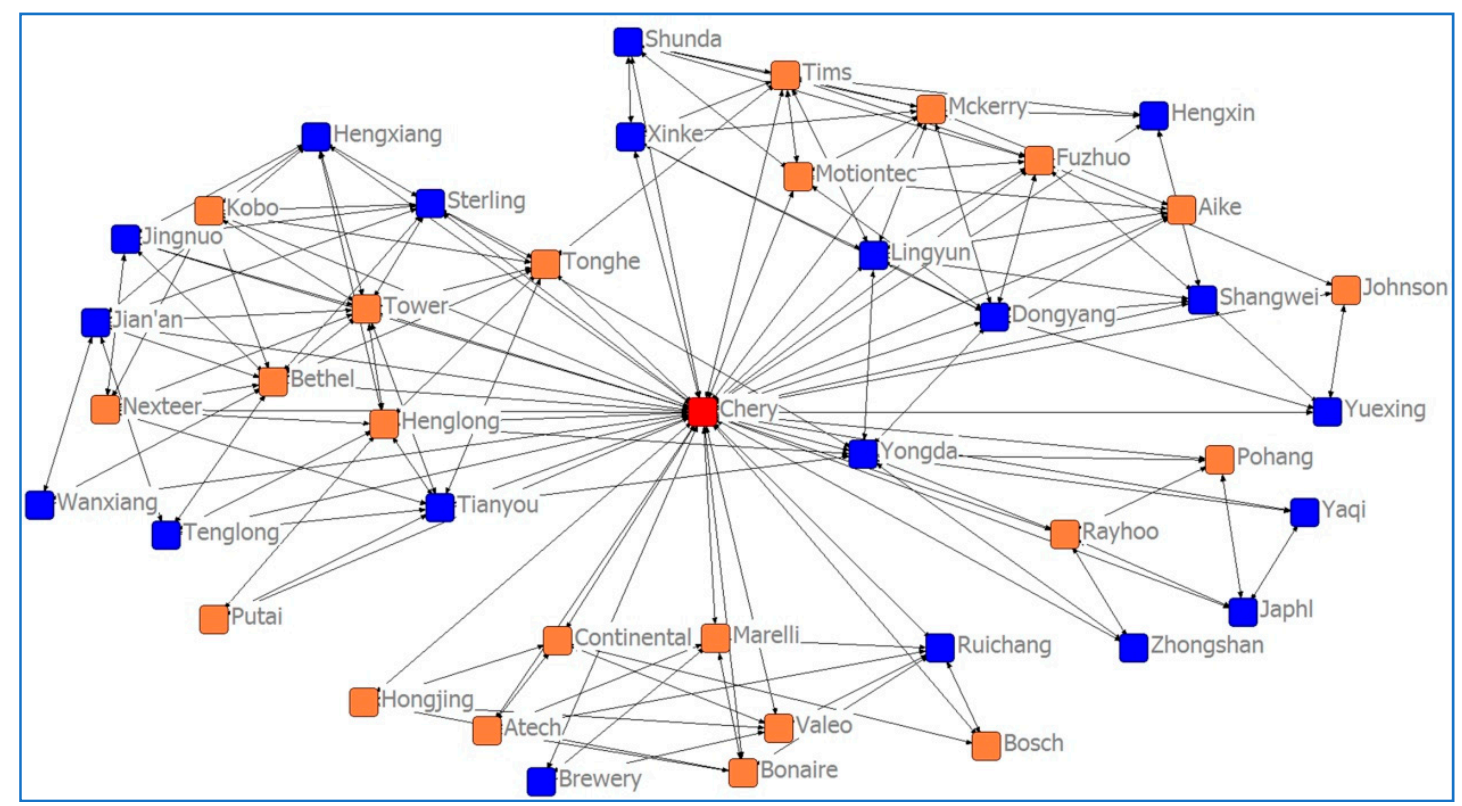

(a) Industrial network.

Figure 3. Cont. 


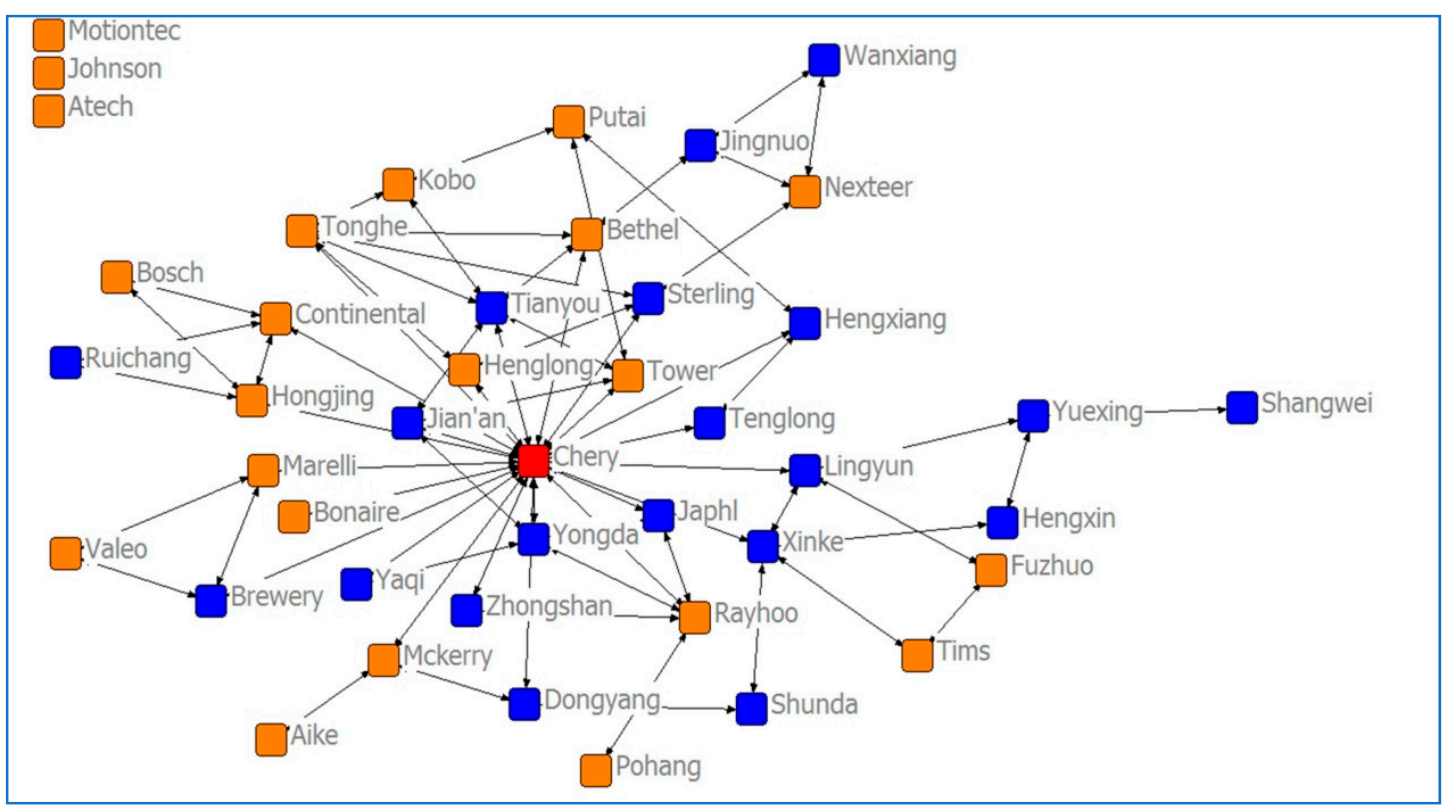

(b) Innovation network.

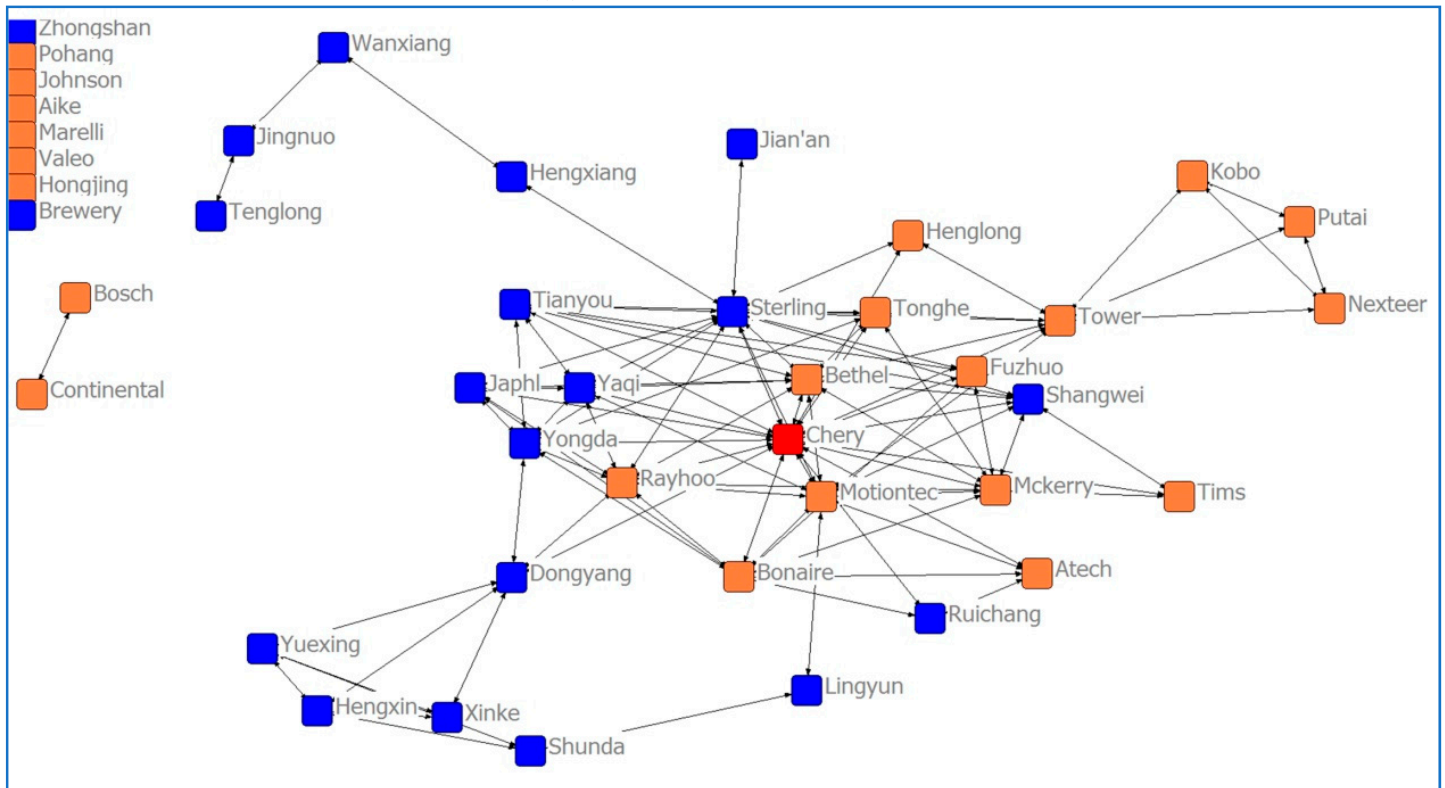

(c) Social network.

Figure 3. The network structures of the Chery auto cluster (the only red square represents Chery; the blue squares represent domestic firms; the orange squares represent cross-border firms). For (a) industrial network; (b) innovation network; and (c) social network, respectively.

We ranked all the firms in each of the networks by assigning 1 to the firm with highest DC value (which is Chery in all the three networks), 2 to the firm with the second highest DC value, and so on. After doing the same for the $\mathrm{BC}$ results, we plotted the firms in the industrial network, technological network, and social network, respectively (Figure 4). 


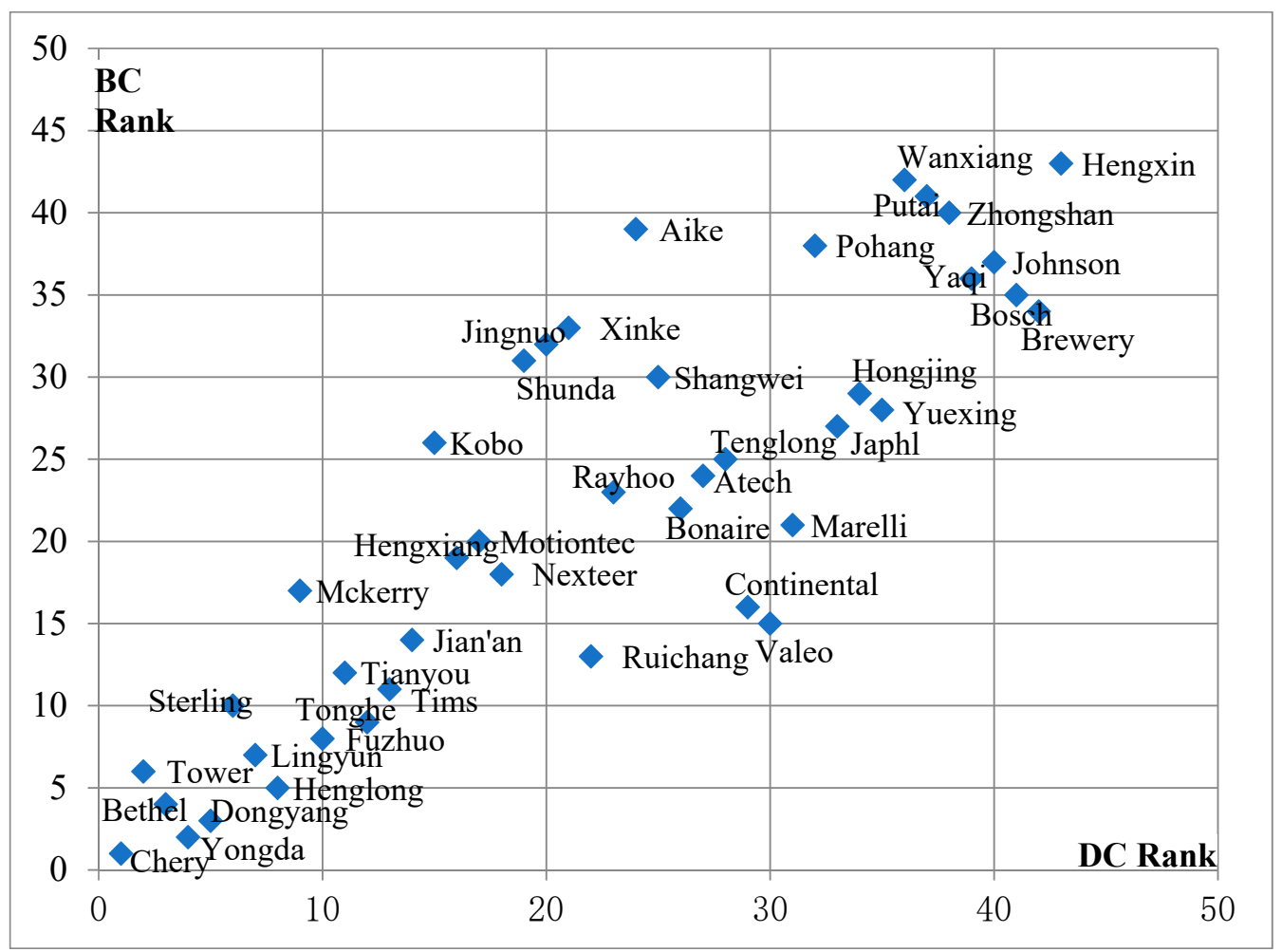

(a) Industrial network.

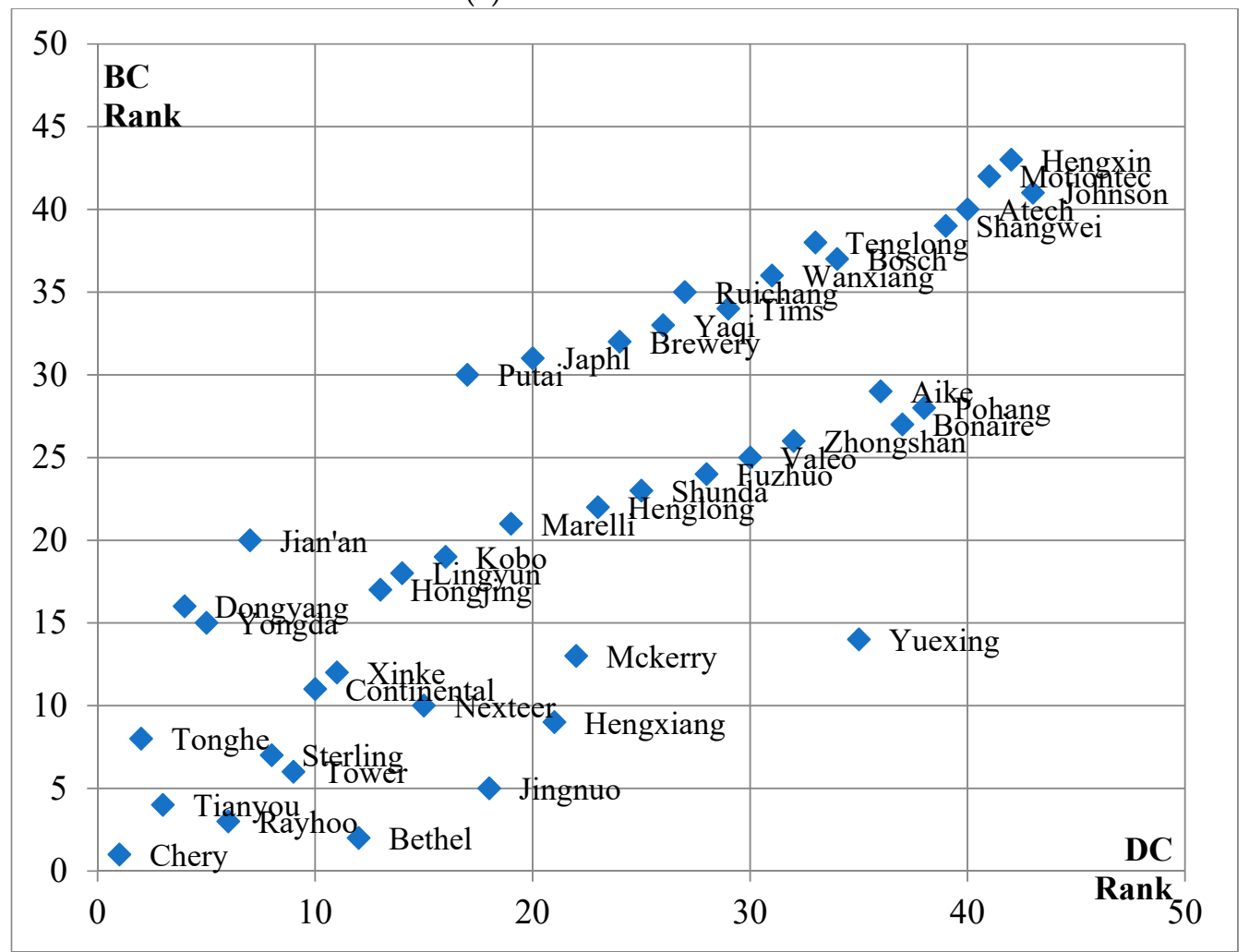

(b) Innovation network.

Figure 4. Cont. 


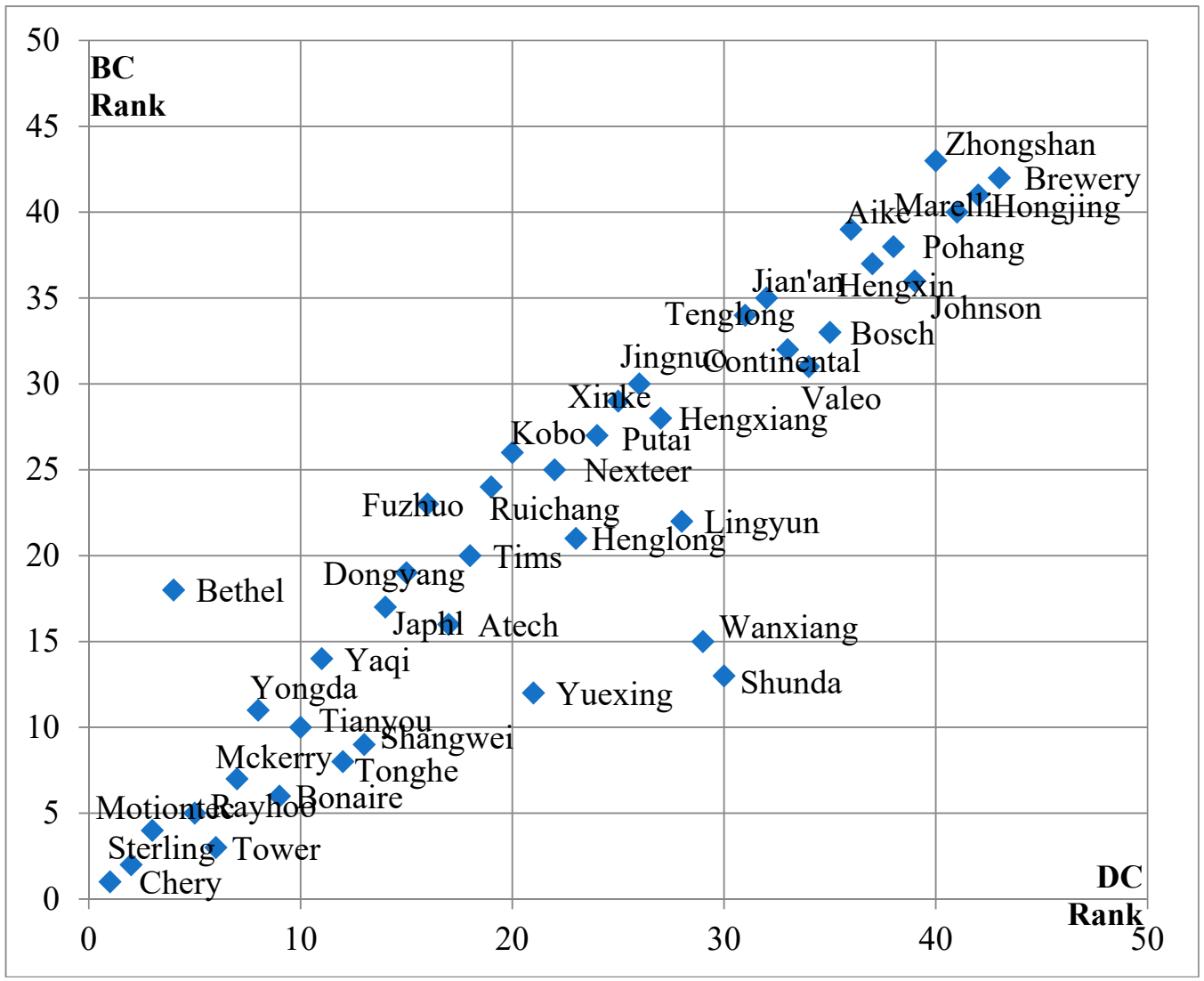

(c) Social network.

Figure 4. Firm ranking by degree centrality (DC) and betweenness centrality (BC), for (a) industrial network; (b) innovation network; and (c) social network, respectively.

Obviously, Chery is the only dominant core in all the three networks. Lead firms are those firms that are well connected to other firms (Figure 3) and have high degrees of centrality (Figure 4), while the peripherals can largely be considered to be the opposite. In the industrial network (Figure 4a), firms with high rankings for both DC and BC, including Tower, Bethel, Yongda, Dongyang, Henglong, Lingyuan, and some others, can be tentatively classified as lead firms. Other firms, especially those firms with lowest rankings of centrality measures, such as Hengxin, Wanxiang, Putai, Zhongshan, Yaqi, and Johnson, etc., can be tentatively considered to be peripherals. In a similar way, in the technological network (Figure 4b), firms, including Tonghe, Tianyou, Rayhoo, Sterling, Tower, Bethel, etc. are considered as lead firms, while Hengxin, Motiontec, Johnson, Atech, Shangwe, etc. appear to be peripherals. Unlike in the industrial network where every firm is linked to at least one other firm (Figure 3a), in the technological network, there are three loners-Motiontec, Johnson, and Atech-that have no technological connection with any other firms (Figure 3b). In the social network, firms such as Sterling, Motiontec, Rayhoo, Tower, Bonaire, Mckerry, etc. appear to be socially active and serve as lead firms, while others are less active and can be considered as peripherals (Figure 4c). Among these peripherals, some firms including Aike, Marelli, Valeo, Hongjing, Zhongshan, Pohang, Johnson, and Brewery, which are extremely inactive socially, are loners (Figure 3c).

Intermediaries are those firms with high value of BC. Their DC, however, may vary. Most of those intermediaries with high values for both DC and BC are also considered as lead firms (as identified previously). There are also some intermediaries with high value of $\mathrm{BC}$ but relatively low value of DC, suggesting that they play an important but more limited role (compared to lead firms) in the network. Such intermediaries include Ruichang, Valeo, Continental, etc., in the industrial network; Jingnuo, Hengxiang, Mckerry, Yuexing, etc., in the technological network; and Yuexing, Shunda, Wanxiang, etc., in the social network. 
By definition, members of a "club of foreigners" may work with each other but they have little or no direct interaction with domestic or local firms (except for Chery). Table 2 lists all the foreign firms under study and their linkages to other foreign and domestic firms (other than Chery). Each number in the table represents the total number of firms that each foreign firm is directly connected in production, technological cooperation, or social interaction. Firms were ranked first in terms of their linkages with domestic order (in an ascending order) and then by their linkages with other foreign firms. As the results in Table 2 show, in the industrial network, Kobo, Aike, Continental, and Atech may be considered to be members of the club as they all have direct production connection with four or more foreign firms but only one domestic firm. In the technological network, Mckerry, Henglong, Kobo, Fuzhuo, and Bosch may be regarded as club members. In the social network, it appears that a larger number of firms fall into this category, including Putai, Lingyun, Kobo, Mckerry, Tower, Fuzhuo, Atech, Henglong, etc.

Table 2. Linkages of foreign firms with domestic firms and other foreign firms.

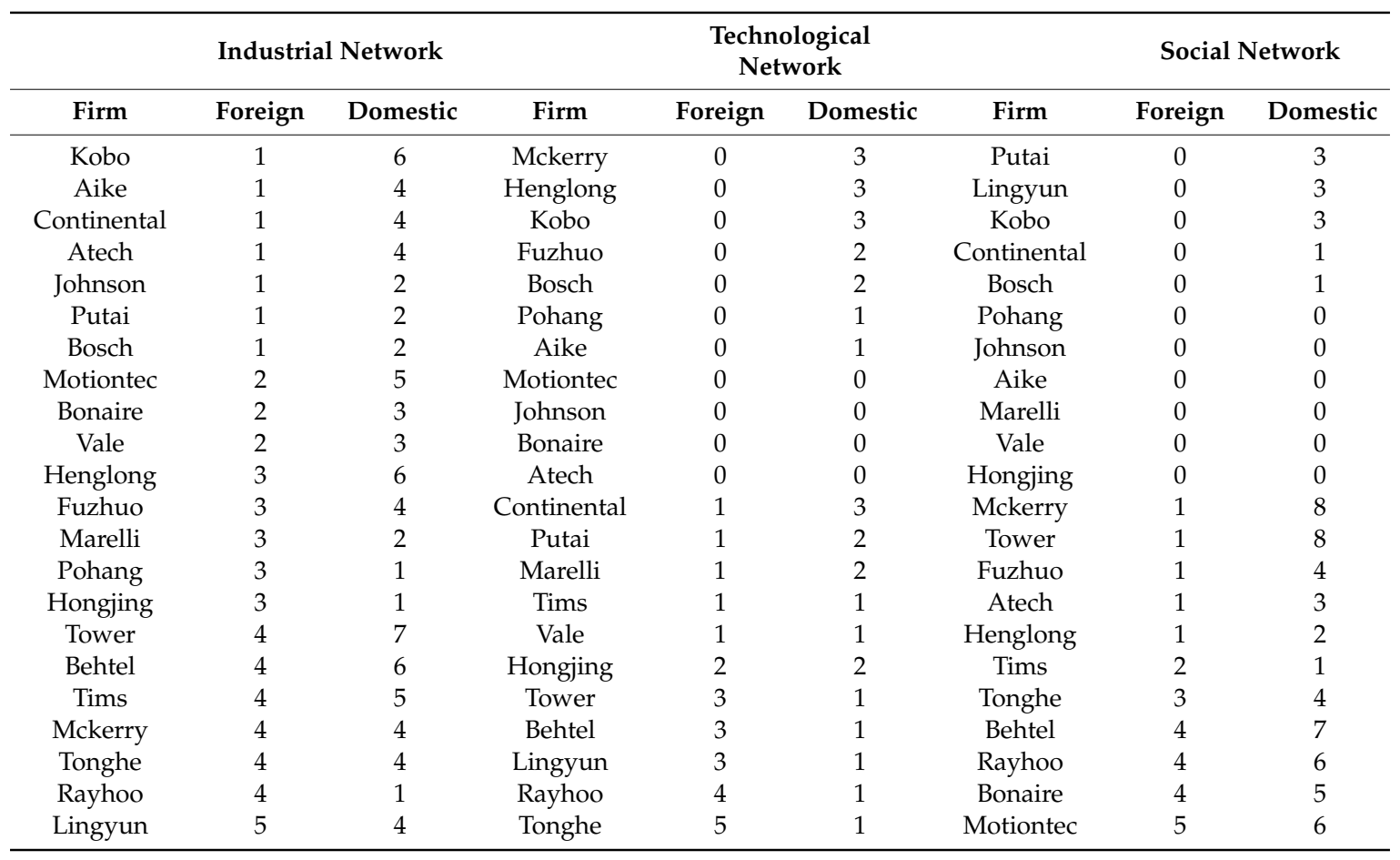

Gatekeepers usually have strong power or influence in the network as they usually control the industrial and information exchange between the cluster and the outside world, but they cannot be easily identified solely based on firms' centrality in the network. The identification of gatekeepers requires a deep and comprehensive understanding of firms and their connections. Based on the interviews with firms, we identified several firms as gatekeepers. In the industrial domain, Tower, Yongda, Bethel, and Dongyan act like gatekeepers. Yongda is a manufacturer of automotive mold. Dongyang is a firm specializing in automotive body and safety system, while Tower and Bethel provide products related to the chassis system. These gatekeepers have close business ties with other firms in the cluster. Suppliers from outside the cluster provide auto parts often through these gatekeepers. According to a company official of Yongda,

"Our company is a strong competitor in the automotive mold field. We supply about $70 \%$ of the powertrain systems and components for Chery. Our company has extensive relationships with firms outside the region. We have a large variety of suppliers. For various reasons, these suppliers do not sell directly to Chery. In other words, they supply Chery with parts and components only through our company." (Transcribed from an interview conducted on 29 October 2015) 
In the technological network, gatekeepers have strong technological assets and close technological relationships with other firms in the cluster. Gatekeepers usually occupy important network positions and have a high degree of centrality.

"We opened the factory in Wuhu in 2002. After more than ten years, we have built technological relationships with many foreign and domestic firms within the Wuhu ETDZ. Chassis companies from outside the region often seek assistance from us in order to get involved in the Chery auto cluster." -Tower company official (Transcribed from an interview conducted on 24 September 2015)

In the social network, gatekeepers have strong social influence and play a very active role coordinating social interactions among firms within the cluster and with outside firms. The research identified Tower, Rayhoo, Sterling, Bonaire, and Yongda as gatekeepers in the social arena. These firms have a relatively long history of investing in Wuhu ETDZ. They have social connections with many other firms and play an active or even leadership role in associations or local community organizations. They actively participate in social events and social life of the community, such as charity functions, donations to schools, and so on.

"There is a Corporate Social Responsibility Council jointly founded by the Wuhu ETDZ Management Committee and Chery. Our company has been elected as an executive council member. The election was recognition of our social contributions. It also raised expectations for our social responsibilities. As you may also know, Chery has a large number and variety of suppliers. It is often very difficult for small firms to organize some social activities. Under this circumstance, these small firms may propose some social events and apply (for approval) through an executive council member like our company, and we take on the role of a 'coordinator'. We have done this for more than ten years, and accumulated a wealth of experience. As a result, our company has good social reputation." - Rayhoo company official (Transcribed from an interview conducted on 28 October 2015)

A classification of Chery's suppliers within different types of network is provided in Table 3.

Table 3. A classification of Chery's supplier firms within the three networks.

\begin{tabular}{|c|c|c|c|}
\hline Firm Type & Industrial Network & Technological Network & Social Network \\
\hline Lead firms & $\begin{array}{l}\text { Tower, Yongda, Dongyang, } \\
\text { Bethel, Mckerry, Tims, } \\
\text { Lingyun, Sterling, Henglong, } \\
\text { Tianyou }\end{array}$ & $\begin{array}{l}\text { Tianyou, Tonghe, Yongda, } \\
\text { Rayhoo, Xinke, Lingyun, } \\
\text { Sterling, Tower, Bethel, Jian'an }\end{array}$ & $\begin{array}{l}\text { Sterling, Motiontec, Bethel, } \\
\text { Rayhoo, Yongda, Mckerry, } \\
\text { Tower, Bonaire, Yaqi, Tianyou }\end{array}$ \\
\hline Intermediaries & $\begin{array}{l}\text { Yongda, Dongyang, Bethel, } \\
\text { Henglong, Tower, Lingyun, } \\
\text { Fuzhuo, Tonghe, Sterling, } \\
\text { Tims, Tianyou, Ruichang, } \\
\text { Jian'an, Valeo }\end{array}$ & $\begin{array}{c}\text { Bethel, Rayhoo, Tianyou, } \\
\text { Jingnuo, Tower, Sterling, } \\
\text { Tonghe, Hengxiang, Nexteer, } \\
\text { Continental, Xinke, Mckerry, } \\
\text { Yuexing, Yongda }\end{array}$ & $\begin{array}{c}\text { Sterling, Tower, Motiontec, } \\
\text { Rayhoo, Bonaire, Mckerry, } \\
\text { Tonghe, Shangwei, Tianyou, } \\
\text { Yongda, Yuexing, Shunda, } \\
\text { Yaqi, Wanxiang }\end{array}$ \\
\hline Club of foreigners & $\begin{array}{c}\text { Johson, Aike, Putai, } \\
\text { Continental, Atech, Motiontec, } \\
\text { Tonghe, Kobo, Bonaire, Valeo }\end{array}$ & $\begin{array}{l}\text { Puhang, Mckerry, Aike, } \\
\text { Henglong, Kobo, Marelli, } \\
\text { Bosch, Fuzhuo, Tims, Putai, } \\
\text { Continental, Valeo }\end{array}$ & $\begin{array}{c}\text { Henglong, Tower, Kobo, } \\
\text { Lingyun, Continental, Bosch, } \\
\text { Fuzhuo, Mckerry, Putai, Atech }\end{array}$ \\
\hline Gatekeepers & $\begin{array}{l}\text { Tower, Yongda, Bethel, } \\
\text { Dongyang }\end{array}$ & $\begin{array}{l}\text { Tonghe, Rayhoo, Tower, } \\
\text { Sterling }\end{array}$ & $\begin{array}{l}\text { Sterling, Yongda, Rayhoo, } \\
\text { Bonaire }\end{array}$ \\
\hline Peripherals & $\begin{array}{l}\text { Nexteer, Hengxiang, } \\
\text { Shangwei, Xinke, Shunda, } \\
\text { Rayhoo, Tenglong, Marelli, } \\
\text { Japhl, Pohang, Yuexing, } \\
\text { Hengxin, Hongjing, Yaqi, } \\
\text { Zhongshan, Jingnuo, } \\
\text { Wanxiang, Bosch, Brewery }\end{array}$ & $\begin{array}{l}\text { Hongjing, Japhl, Dongyang, } \\
\text { Brewery, Yaqi, Zhongshan, } \\
\text { Shunda, Hengxin, Wanxiang, } \\
\text { Tenglong, Ruichang, } \\
\text { Shangwei, Bonaire }\end{array}$ & $\begin{array}{l}\text { Japhl, Dongyang, Hengxin, } \\
\text { Xinke, Tims, Nexteer, } \\
\text { Ruichang, Jingnuo, } \\
\text { Hengxiang, Jian'an, Tenglong }\end{array}$ \\
\hline Loners & & Motiontec, Johnson, Atech & $\begin{array}{l}\text { Zhongshan, Pohang, Johnson, } \\
\text { Aike, Marelli, Valeo, Hongjing, } \\
\text { Brewery }\end{array}$ \\
\hline
\end{tabular}




\subsubsection{Firms' Role in the Chery Auto Cluster: A Comprehensive Identification}

In the previous subsection, we defined the major roles that firms play in each of the networks (industrial, technological, and social). The results show that in different domains, the same firm may play different roles and occupy different positions. In a few cases, a lead firm in a network occupies a less important position and plays a minor role in another network. To gain a whole picture of firms' role in the Chery auto cluster, we performed a comprehensive identification of firms' role following a simple rule: we define a firm's role in the cluster if it played the same role in at least two networks out of the total three (Table 4). We put the dominant core, lead firms, intermediaries with higher DC, and gatekeepers in a broad category and call them "core firms". Overall, these firms have extensive linkages to other firms, occupy central or critical positions in the network, and have strong production, technological, and social power in relation to others. Some other firms, including member of the club of foreigners, intermediaries with lower DC, loners, and some others were put in the category "peripheral firms" as they are less connected and play less dominant role (compared to the core firms) in the cluster.

Table 4. Firms' role in the Chery auto cluster: a comprehensive identification.

\begin{tabular}{|c|c|c|}
\hline Category & Role & Firms \\
\hline \multirow{4}{*}{ Core Firms } & Dominant core & Chery \\
\hline & Lead firms & Tower, Yongda, Sterling, Rayhoo, Bonaire, Bethel, Tianyou \\
\hline & Intermediaries (high DC) & Tower, Bethel, Yongda, Sterling, Tianyou, Bonaire \\
\hline & Gatekeepers & Rayhoo, Sterling, Tower, Yongda, Bonaire \\
\hline \multirow{4}{*}{$\begin{array}{l}\text { Peripheral } \\
\text { Firms }\end{array}$} & "Club of foreigners" & $\begin{array}{c}\text { Fuzhuo, Mckerry, Aike, Henglong, Putai, Kobo, Continental, } \\
\text { Atech, Bosch }\end{array}$ \\
\hline & Intermediaries (low DC) & Tonghe, Lingyun, Henglong, Mckerry, Tims, Motiontec \\
\hline & Loners & Johnson, Zhongshan, Brewery, Marelli, Valeo \\
\hline & Other peripherals & $\begin{array}{c}\text { Yaqi, Japhl, Shangwei, Xinke, Yuexing, Shunda, Hengxin, } \\
\text { Dongyang, Jingnuo, Nexteer, Jian'an, Wanxiang, Hengxiang, } \\
\text { Ruichang, Hongiing }\end{array}$ \\
\hline
\end{tabular}

Several important findings deserve to be highlighted. First, the results of the research reveal the heterogeneity of firms and the diverse role they play in a localized production network. Some firms may play multiple roles. Some core firms, for instance, such as Tower, Yongda, Sterling, etc., also act as intermediaries and gatekeepers. They play critical role in connecting firms and coordinating activities within the cluster, as well as in connecting the cluster with the outside world. Secondly, among all the suppliers in the Chery auto cluster, foreign firms seem to be more powerful than domestic firms. Among the seven lead firms identified, five are subsidiaries of foreign TNCs and only two firms - Yongda and Sterling - are domestic firms (both headquartered in Zhejiang). Thirdly, some firms (both foreign and domestic), such as Yaqi, Dongyang, Kobo, and Valeo, have a fairly large presence in the Wuhu ETDZ and strong technological capabilities. As latecomers, however, they have not achieved the status of core firms. Over time, their influence in the cluster is expected to rise. Fourthly, the study revealed the existence of a "club of foreigners" in the cluster. Club members have few ties to the local community. The lack of interaction with domestic firms especially with local firms limits the knowledge spillover of foreign investor firms, which, from the host region's perspective, is not conducive to regional development. Fifthly, most gatekeepers are foreign firms, and Yongda is the only domestic company. This poses potential risks to the local production network. Lastly, in the technological and social networks, some firms occupy very isolated positions and have little interaction with other actors. 


\subsubsection{Firm's Role in the Industrial Cluster: Influencing Factors}

The position of a firm and the role it plays in a production network are influenced by many factors. Here, we focus on three factors, including firm attributes, firm's corporate strategies, and firm's embeddedness.

Firm attributes, such as corporate scale and size, origin, corporate culture, determine what a firm offers and influence how it interacts with other actors in the network, and thus affect the position of the firm in the network and the role it plays. The central positions of lead suppliers such as Tower, Rayhoo, Sterling, Bonaire, and Yongda, in the cluster, are attributable to the size and technological capabilities of these companies (or their parent companies) as well as the scale of their investments in the Wuhu ETDZ. They also have to do with the products they provide. These firms supply critical parts or components that are needed for the major vehicle systems (powertrain system, body system, chassis system, and electronics system). In contrast, many smaller firms only supply some generic parts to Chery, and often times they do that through the lead firms.

It is well known that corporate culture influence firms' behaviors and location decisions. European and North American companies, for example, tend to have a competitive and individualist corporate culture, while many Asian companies often put an emphasis on collectivism and personalized relations (or guanxi). Accordingly, Western firms often work on an individual, competitive basis when they first enter a local production network; while large Asian companies may bargain to bring suppliers and other related firms to come together. This seems to be true within the Chery auto cluster. Companies like Johnson, Aike, Valeo, Bosch, and Continental are all world top 500 companies with strong technological and production capacities. However, each of these firms came to Wuhu ETDZ alone and relatively recently and did not actively seek partnerships with other firms during the entry stage and early phases of development. Partly for this reason, those firms have not climbed to a central position in the cluster. By contrast, companies from Mainland China, Taiwan and Hong Kong, such as Yongda, Sterling, Tianyou, Tonghe, and Rayhoo, adopted a different approach. Some of them came with their own suppliers or industrial partners. After their arrival, these firms actively sought partnerships with other firms (foreign, domestic, and local), quickly forming a cluster of their own. This approach helped these firms occupy a central position in the network.

Firm's corporate strategies and investment decisions also influence their positioning in a network. Different firms make investment decisions based on different criteria. While some firms choose to invest in particular places in order to gain access to resources, cheap or high-quality labor, or market, others open new business in an industrial cluster to gain access to technology and knowledge, or to take advantage of investment incentives provided by the government. Generally speaking, firms seeking access to labor or local market are less motivated to establish linkages with local firms. Instead, they usually retain the connections with the previous upstream and downstream partners. This phenomenon may explain the behavior of some foreign firms including the club of foreigners, loners, and some other firms in the Chery auto cluster, which leads to their peripheral positions. On the other hand, if a firm invests in a region attracted by the region's industrial support capabilities or to exploit the technological strength of the region, it tends to actively seek partnerships to be integrated in the network. This seems to be the case for many domestic firms. They invest in the Wuhu ETDZ not only to get access to the market created by Chery, but also to improve technological capabilities.

To be sure, firms' corporate strategies may change over time, along with changing development priorities. Chery, for example, has experienced several transformations since it was founded in 1997. The company's development strategy has evolved from developing and securing core technologies to optimizing cost and then to sustainable growth (interview with Chery CEO). During 1997-2005, in order to harness the knowledge spillover benefits of FDI, Chery worked with the Wuhu ETDZ Management Committee to attract world top 500 enterprises and leading auto part companies to invest in the Wuhu ETDZ. During 2006-2010, Chery's investment priority was shifted to the domestic auto parts industry to reduce production costs and realize comparative advantage. In 2011, Chery announced its "One Brand" strategy to strength its name. The company has expanded its R\&D and 
integrated its distribution networks. In response to the changes in Chery's development priorities, other firms in the cluster have also adjust their development strategies over time. According to the senior company official of Rayhoo (a major auto body parts provider),

"The reason we chose to invest in Wuhu ETDZ was to be close to and work with Chery to make profit. But Chery makes strategic adjustments, we have to adjust our own development strategies too in order to upgrade and diversify our products, expand our market, and achieve brand success. Therefore, our role (in the industrial cluster) has evolved over time, from a supplier to intermediary and then to a lead firm (in the network). We even control some supply chains that connect Chery with firms outside the region." (Transcribed from an interview conducted on 28 October 2015)

A firm's position in the network and the role it plays also have to do with how it handles environmental factors and interacts with other actors. Firms' successful embeddedness in the local network is crucial not only for their performance but also for the development of the local cluster. In reality, the nature and degree of local embeddedness varies among firms. The research shows that some firms have pursued "active embeddedness" by actively seeking out localized assets and incorporating them within its operations. Some firms, especially domestic firms such as Sterling and Tianyou, worked closely with Chery and actively sought partnerships with other actors in the cluster. They often make rapid adjustments in response to the changing business environment.

"Our company experienced difficulties in 2011 due to Chery's transformation and increased requirements for product quality. Even though we had the technological capabilities, there were problems in production and post-production services. We made efforts to address them and have seen significant improvement in management." - Sterling company official (Transcribed from an interview conducted on 27 October 2015)

Meanwhile, some firms, many of which are foreign firms (such as Atech, Kobo, Mckerry, Henglong, Bosch, etc. in the club of foreigners, or Johnson as a loner), have not been effectively integrated into the local cluster. They either have not actively sought partnerships with other firms, or have not successfully adapted themselves to the local environment and management culture.

"My company has not adapted itself to the local environment. The challenges exist in several areas. First, there are some differences in corporate management culture. For example, the popular performance method used in China is not supported in our company. Secondly, we did not do a good job in recruiting and retaining talent. Thirdly, our company is a joint venture, and sometimes we cannot make a decision on some issues because stakeholders cannot reach an agreement." -Mckerry company official (Transcribed from an interview conducted on 27 October 2015)

\section{Summary and Concluding Remarks}

This paper has demonstrated how industrial clusters contribute to sustainable regional economic development. Wuhu, a mid-sized city in Anhui Province in eastern China, has recorded rapid economic growth since the mid-1990s. The establishment of the Wuhu ETDZ and formation of the Chery auto cluster have played an important role in the city's economic success.

The study has revealed the heterogeneity of the roles that firms play in a localized production network - the Chery auto cluster. Based on firms' network positions and network power, we defined a typology of roles including the dominant core, lead firms, gatekeepers, intermediaries, club of foreigners, peripherals, and loners. The definitions of these roles, however, are not completely exclusive, as some firms play multiple roles. Many factors influence what position a firm occupies in the network and what role it plays, including, for example, the size and technological capabilities of the firm (or its parent company), the history of presence, corporate strategies, and the degree of local embeddedness. Overall, subsidiaries of foreign TNCs tend to occupy important positions in the network of suppliers within the Chery cluster. Still, some foreign firms, despite their technological 
strength, occupy an isolated position and play a less than proportional role, due to their late arrival, lack of interest in seeking partnership with domestic or local firms, or a combination of these factors. The study also demonstrated that as firms grow or adjust, their corporate development strategies in response to the changing business environment, their role in the network may change over time.

The findings for the study have several implications for policy makers and regional planners. First, given their importance, local governments may consider offering more policy support to Chery and lead firms to strengthen their technological capabilities and to encourage their upgrading as well as their "joint upgrading" with their subcontractors [60]. This is critical for the upgrading of the industrial cluster, which is essential for future sustainable growth of the region. Secondly, from the host region's perspective, the existence of "club of foreigners" is not conducive to sustainable regional economic development because the lack of interaction with domestic firms limits the knowledge spillover of foreign investor firms. After all, members in this club have strong technological capabilities, and technological leaders are expected to undertake a "knowledge dissemination" task and act as knowledge givers [61]. To address the issue, Wuhu ETDZ Management Committee, with the help from various associations and organizations, may encourage and promote networking among members through social events and professional activities. Thirdly, the dominance of foreign firms poses potential risks to the local production network. TNCs often play a critical role in nurturing the development of a local production network. They are also known be highly mobile. When these gatekeepers decide to relocate for various reasons (e.g., rising labor cost, expiration of investment incentives, changing regulatory environment, to name a few), it could greatly impact other firms and cause tremendous damage to the cluster. Large domestic firms should be encouraged to establish direct business ties with suppliers and contractors outside the region. This will reduce the aforementioned risk and help prevent the cluster from becoming a closed network and falling into a regional lock-in [62,63]. Lastly, for firms that occupy very isolated positions and have little interaction with other actors, the failure of being fully integrated into the network not only impedes the growth and development of these loner firms, but also creates obstacles to the growth and upgrading of the entire industrial cluster. To help them grow and strength their roles in the cluster, measures (similar to those taken for the club of foreigners) could be taken to help these firms to network with other firms.

Author Contributions: X.C. designed the research. X.C. and E.W. revised methodology. X.C. and L.J. conducted investigation. X.C performed main analysis. E.W., C.M. and S.P. validated the results. L.J. helped data visualization and project administration. X.C. and E.W. prepared the original draft. E.W., X.C. and C.M. revised and edited the paper. X.C., C.M. and S.P. acquired funding and secured resources. All authors have read and agreed to the published version of the manuscript.

Funding: This research was funded by National Natural Science Foundation of China (grant numbers 41901149 and 41430637) and China Postdoctoral Science Foundation (grant number 2017M622332).

Conflicts of Interest: The authors declare no conflict of interest. 


\section{Appendix A}

Table A1. List of firms studied in Wuhu Economic and Technological Development Zone (Wuhan ETDZ).

\begin{tabular}{|c|c|c|c|}
\hline $\begin{array}{l}\text { Product } \\
\text { Category }\end{array}$ & Full Name & Abbreviation & Origin \\
\hline & Chery Automobile Co., Ltd. & Chery & Wuhu, Anhui \\
\hline \multirow{6}{*}{$\begin{array}{c}\text { Powertrain } \\
\text { System }\end{array}$} & Yongda Technology Co., Ltd. & Yongda & Zhejiang \\
\hline & Yaqi Automotive Parts Co., Ltd. & Yaqi & Jiangsu \\
\hline & Japhl Powertrain System Co,.Ltd & Japhl & Anhui \\
\hline & RayhooHaobo Mold Technology Co., Ltd. & Rayhoo & Taiwan \\
\hline & Zhongshan Equipment Engineering Co., Ltd. & Zhongshan & Anhui \\
\hline & Pohang Automotive Parts Manufacturing Co., Ltd. & Pohang & Korea \\
\hline \multirow{13}{*}{ Body System } & Motiontec Automotive Technology Co., Ltd. & Bethel & Taiwan \\
\hline & Shangwei Automobile Accessories Co., Ltd. & Shangwei & Shanghai \\
\hline & Xinke Automotive Parts Co., Ltd. & Xinke & Shanghai \\
\hline & Fuzhuo Automobile Interior Co., Ltd. & Fuzhuo & Australia \\
\hline & Mckerry Automotive Exterior Co., Ltd. & Mckerry & Canada \\
\hline & Tims Automotive Technology Co., Ltd. & Tims & Japan \\
\hline & Yuexing Automobile Ornaments Co., Ltd. & Yuexing & Liaoning \\
\hline & Shunda Automotive Accessories Co., Ltd. & Shunda & Jilin \\
\hline & Hengxin Automotive Interior Manufacturing Co., Ltd. & Hengxin & Zhejiang \\
\hline & Johnson Controls Automotive Trim Co., Ltd. & Johnson & U.S. \\
\hline & Aike Automobile Technology Co., Ltd & Aike & U.S. \\
\hline & Dongyang Automotive Plastic Parts Co., Ltd. & Dongyang & Taiwan \\
\hline & Lingyun Industrial Co., Ltd. & Lingyun & Hebei \\
\hline \multirow{14}{*}{ Chassis System } & Tianyou Automotive Engineering Co., Ltd. & Tianyou & Zhejiang \\
\hline & Tonghe Automotive Pipeline System Co., Ltd. & Tonghe & Hong Kong \\
\hline & Sterling Steering System Co., Ltd. & Sterling & Zhejiang \\
\hline & Henglong Automobile Steering System Co., Ltd. & Henglong & Hong Kong \\
\hline & Tower Automotive Products Co., Ltd. & Tower & U.S. \\
\hline & Bethel Automotive Safety Systems Co., Ltd. & Bethel & Canada \\
\hline & Putai Automotive Technology Co., Ltd. & Putai & U.S. \\
\hline & Jingnuo Automotive Electric Co., Ltd. & Jingnuo & Jiangsu \\
\hline & Nexteer Driveline System Co., Ltd. & Nexteer & U.S. \\
\hline & Jian'an Chassis System Co., Ltd. & Jian'an & Sichuan \\
\hline & Wanxiang System Co., Ltd. & Wanxiang & Zhejiang \\
\hline & Hengxiang Industrial Co., Ltd. & Hengxiang & Zhejiang \\
\hline & Tenglong Automotive Parts Manufacturing Co., Ltd. & Tenglong & Jiangsu \\
\hline & Kobo Auto Parts Co., Ltd. & Kobo & U.S. \\
\hline \multirow{9}{*}{$\begin{array}{l}\text { Electronics } \\
\text { System }\end{array}$} & Continental Automotive Interior Co., Ltd. & Continental & Germany \\
\hline & Bonaire Automotive Electrical Systems Co., Ltd. & Bonaire & U.S. \\
\hline & Atech-Automotive Co., LTD & Atech & U.S. \\
\hline & Ruichang Automotive Electric System Co., Ltd. & Ruichang & Guangdong \\
\hline & Brewery Automotive Parts Co., Ltd. & Brewery & Guangxi \\
\hline & Marelli Automotive Parts Co., Ltd. & Marelli & Italy \\
\hline & Valeo Automotive Lighting Systems Co., Ltd. & Valeo & France \\
\hline & Bosch Automotive Multimedia Co., Ltd. & Bosch & Germany \\
\hline & Hongjing Electronics Co., Ltd. & Hongjing & Taiwan \\
\hline
\end{tabular}

\section{References}

1. Porter, M.E. Clusters and new economics of competition. Harv. Bus. Rev. 1998, 6, 77-90.

2. Iammarino, S.; McCann, P. The structure and evolution of industrial clusters: Transactions, technology and knowledge spillovers. Res. Policy 2006, 35, 1018-1036. [CrossRef]

3. Papalia, R.B.; Bertarelli, S. The role of local agglomeration economies and regional characteristics in attracting FDI: Italian evidence. Int. J. Econ. Bus. 2009, 16, 161-188. [CrossRef] 
4. Perri, A. Innovation and the Multinational Firm: Perspectives on Foreign Subsidiaries and Host Locations; Palgrave Macmillan: New York, NY, USA, 2014.

5. Lambert, T.E.; Mattson, G.A.; Dorriere, K. The impact of growth and innovation clusters on unemployment in US metro regions. Reg. Sci. Polict. Pract. 2017, 9, 25-37. [CrossRef]

6. Boschma, R. New industries and windows of locational opportunity: A long-term analysis of Belgium. Erdkunde. 1997, 51, 1-19. [CrossRef]

7. Gereffi, G. The organization of buyer-driven commodity chains: How US retailers shape overseas production networks. In Commodity Chains and Global Capitalism; Gereffi, G., Korzeniewicz, M., Eds.; Greenwood Press: Westport, CT, USA, 1994; pp. 95-122.

8. Gereffi, G. International trade and industrial upgrading in the apparel commodity chain. J. Int. Econ. 1999, 48, 37-70. [CrossRef]

9. Gereffi, G. Global Value Chains and Development: Redefining the Contours of 21st Century Capitalism; Cambridge University Press: New York, NY, USA, 2018.

10. Gereffi, G.; Humphrey, J.; Sturgeon, T. The governance of global value chains. Rev. Int. Polit. Econ. 2005, 12, 78-104. [CrossRef]

11. Kaplinsky, R. Competitions Policy and the Global Coffee and Cocoa Value Chains; UNCTAD: Geneva, Switzerland, 2004.

12. Navas-Alemán, L. The impact of operating in multiple value chains for upgrading: The case of the Brazilian furniture and footwear industries. World Dev. 2011, 39, 1386-1397. [CrossRef]

13. Coe, N.M.; Yeung, H.W.C. Global production networks: Theorizing economic development in an interconnected world. OUP Catalogue 2015, 16, 539-540.

14. Wang, J.H.; Lee, C.K. Global production networks and local institution building: The development of the information-technology industry in Suzhou, China. Environ. Plann A 2007, 39, 1873-1888. [CrossRef]

15. Yang, Y.R.; Hsia, C.J. Spatial clustering and organizational dynamics of transborder production networks: A case study of Taiwanese information-technology companies in the Greater Suzhou Area, China. Environ. Plann A 2007, 39, 1346-1363. [CrossRef]

16. Yeung, H.W.C. Industrial clusters and production networks in Southeast Asia: A global production networks approach. In Production Networks and Industrial Clusters: Integrating Economies in Southeast Asia; Kuroiwa, I., Heng, T.M., Eds.; Institute of Southeast Asian Studies: Singapore, 2008; pp. 83-120.

17. Christopherson, S.; Clark, J. Power in firm networks: What it means for regional innovation systems. Reg. Stud. 2007, 41, 1223-1236. [CrossRef]

18. Rutherford, T.; Holmes, J. 'The flea on the tail of the dog': Power in global production networks and the restructuring of Canadian automotive clusters. J. Econ. Geogr. 2008, 8, 519-544. [CrossRef]

19. Granovetter, M. Economic action and social structure: The problem of embeddedness. Am. J. Sciol. 1985, 91, 481-510. [CrossRef]

20. Gnyawali, D.R.; Madhavan, R. Cooperative networks and competitive dynamics: a structural embeddedness perspective. Acad. Manag. Rev. 2001, 26, 431-445. [CrossRef]

21. Audretsch, D.B.; Lehmann, E.E. Does the knowledge spillover theory of entrepreneurship hold for regions? Res. Policy 2005, 34, 1191-1202. [CrossRef]

22. $\mathrm{Fu}, \mathrm{W}$. Industrial clusters as hothouses for nascent entrepreneurs? the case of Tianhe Software Park in Guangzhou, China. Ann. Reg. Sci. 2016, 57, 253-270. [CrossRef]

23. Belussi, F.; Hervas-Oliver, J.L. Cluster advantage and firm performance: A concluding remark. In Agglomeration and Firm Performance; Belussi, F., Hervas-Oliver, J.L., Eds.; Springer: Berlin, Germany, 2018; pp. 309-324.

24. Boschma, R.; Balland, P.A.; Kogler, D. The geography of inter-firm knowledge spillovers in biotech. In The Economics of Knowledge, Innovation and Systemic Technology Policy; Crespi, F., Quatraro, F., Eds.; Routledge: New York, NY, USA, 2015; pp. 147-169.

25. Broekel, T.; Boschma, R. The cognitive and geographical structure of knowledge links and how they influence firms' innovation performance. Region. Stat. 2016, 6, 3-26. [CrossRef]

26. Liu, W.; Dicken, P. Transnational corporations and 'obligated embeddedness': Foreign direct investment in China's automobile industry. Environ. Plann A 2006, 38, 1229-1247. [CrossRef]

27. Burt, S.; Johansson, U.; Dawson, J. Dissecting embeddedness in international retailing. J. Econ. Geogr. 2017, 17, 685-707. [CrossRef] 
28. Grabher, G. The disembedded regional economy: The transformation of East German industrial complexes into western enclaves. In Globalization, Institutions, and Regional Development in Europe; Amin, A., Thrift, N., Eds.; Oxford University Press: Oxford, UK, 1994; pp. 177-195.

29. Bell, M.; Albu, M. Knowledge systems and technological dynamism in industrial clusters in developing countries. World Dev. 1999, 27, 1715-1734. [CrossRef]

30. Pan, F.; Wang, J. From obligated embeddedness to supplier chain park investment: A new mode of FDI? China Soft Sci. Mag. 2010, 3, 95-102.

31. Chen, X.; Miao, C.; Pan, S.; Ai, S. Characteristics and construction mechanism of enterprise networks in "Hub- and- Spoke" cluster: Empirical evidence from Chery cluster in 2014, China. Geogr Res. 2018, 37, 353-365.

32. Wasserman, S.; Faust, K. Social Network Analysis: Methods and Applications; Cambridge University Press: New York, NY, USA, 1994.

33. Batt, P.J.; Purchase, S. Managing collaboration within networks and relationships. Ind. Market. Manag. 2004, 33, 169-174. [CrossRef]

34. Boschma, R.A.; TerWal, A.L. Knowledge networks and innovative performance in an industrial district: The case of a footwear district in the South of Italy. Ind. Innov. 2007, 14, 177-199. [CrossRef]

35. Prell, C.; Hubacek, K.; Reed, M. Stakeholder analysis and social network analysis in natural resource management. Soc. Nat. Resour. 2009, 22, 501-518. [CrossRef]

36. Pauget, B.; Wald, A. Relational competence in complex temporary organizations: The case of a French hospital construction project network. Int. J. Projt. Manag. 2013, 31, 200-211. [CrossRef]

37. Dolfsma, W.; Van der Eijk, R. Network position and firm performance-the mediating role of innovation. Technol. Anal. Strateg. Manag. 2017, 29, 556-568. [CrossRef]

38. Chuluun, T.P.; Prevost, A.; Upadhyay, A. Firm network structure and innovation. J. Corp. Financ. 2017, 44, 193-214. [CrossRef]

39. Pavlínek, P.; Ženka, J. Upgrading in the automotive industry: Firm-level evidence from Central Europe. J. Econ. Geogr. 2010, 11, 559-586. [CrossRef]

40. Li, Y.; Kong, X.; Zhang, M. Industrial upgrading in global production networks: The case of the Chinese automotive industry. Asia Pac. Bus. Rev. 2016, 22, 21-37. [CrossRef]

41. Pavlínek, P.; Žížalová, P. Linkages and spillovers in global production networks: Firm-level analysis of the Czech automotive industry. J. Econ. Geogr. 2016, 16, 331-363. [CrossRef]

42. Sturgeon, T.; Van, B.J.; Gereffi, G. Value chains, networks and clusters: Reframing the global automotive industry. J. Econ. Geogr. 2008, 8, 297-321. [CrossRef]

43. Pavlínek, P. Global production networks, foreign direct investment, and supplier linkages in the integrated peripheries of the automotive industry. Econ. Geogr. 2018, 94, 141-165. [CrossRef]

44. Anaya, L.G. Knowledge transfer in the automotive industry: The case of JICA's project for automotive supply chain development in Mexico. Méx Cuenca Pac. 2019, 23, 93-122. [CrossRef]

45. Khan, Z.; Shenkar, O.; Lew, Y.K. Knowledge transfer from international joint ventures to local suppliers in a developing economy. J. Int. Bus. Stud. 2015, 46, 656-675. [CrossRef]

46. Kramer, J.P.; Diez, J.R. Catching the local buzz by embedding? Empirical insights on the regional embeddedness of multinational enterprises in Germany and the UK. Reg. Stud. 2012, 46, 1303-1317. [CrossRef]

47. Rugraff, E.; Sass, M. How did the automotive component suppliers cope with the economic crisis in Hungary? Eur.-Asia Stud. 2016, 68, 1396-1420. [CrossRef]

48. Eisingerich, A.B.; Bell, S.J.; Tracey, P. How can clusters sustain performance? The role of network strength, network openness, and environmental uncertainty. Res. Policy 2010, 39, 239-253. [CrossRef]

49. Plum, O.; Hassink, R. Analysing the knowledge base configuration that drives southwest Saxony's automotive firms. Eur. Urban Reg Stud. 2013, 20, 206-226. [CrossRef]

50. Shen, Y.J.; Yu, S.L.; Zhu, D. Rising labor costs, industrial transfer and firm value: A case study on Foxconn's immigration. J. Account. Econ. 2017, 31, 56-70.

51. Turkina, E.; Van Assche, A.; Kali, R. Structure and evolution of global cluster networks: Evidence from the aerospace industry. J. Econ. Geogr. 2016, 16, 1211-1234.

52. SBA (Statistical Bureau of Anhui) Anhui Statistical Yearbook; China Statistics Press: Beijing, China, 2018. 
53. Wuhu Economic and Technological Development Zone (ETDZ), Wuhu Economic and Technological Development Zone—Profile. Available online: http://www.weda.gov.cn/UserData/SortHtml/539/59219796547. html (accessed on 10 June 2019).

54. Liu, Y. The dynamics of local upgrading in globalizing latecomer regions: A geographical analysis. Reg. Stud. 2017, 51, 880-893. [CrossRef]

55. Han, F.; Xi, Q.; Ma, T. Building competitive advantage of locations for automobile industry: Changchun as the example. Int. J. Bus. Manag. 2008, 3, 107-112. [CrossRef]

56. Depner, H.; Bathelt, H. Exporting the German model: The establishment of a new automobile industry cluster in Shanghai. Econ. Geogr. 2005, 81, 53-81. [CrossRef]

57. Chu, W. How the Chinese government promoted a global automobile industry. Ind. Corp. Chang. 2011, 20, 1235-1276. [CrossRef]

58. Borgatti, S.P.; Everett, M.G. Models of core/periphery structures. Soc. Netw. 1999, 21, 375-395. [CrossRef]

59. Yeung, H.W.C. Strategic Coupling: East Asian Industrial Transformation in the New Global Economy; Cornell University Press: Ithaca, NY, USA, 2016.

60. Lowe, B. Design driven innovation: Changing the rules of competition by radically innovating what things mean. Res. Tech. Manag. 2009, 52, 67-68.

61. Wang, C. Geography of knowledge sourcing, search breadth and depth patterns, and innovative performance: A firm heterogeneity perspective. Environ. Plann A 2015, 47, 744-761. [CrossRef]

62. Markusen, A. Sticky places in slippery space: A typology of industrial districts. Econ. Geogr. 1996, 72, 293-313. [CrossRef]

63. Martin, R.; Sunley, P. Path dependence and regional economic evolution. Papers Evol. Econ. Geogr. 2006, 6, 395-437. [CrossRef]

(C) 2020 by the authors. Licensee MDPI, Basel, Switzerland. This article is an open access article distributed under the terms and conditions of the Creative Commons Attribution (CC BY) license (http://creativecommons.org/licenses/by/4.0/). 